\title{
Hydrological investigations in the semi-arid Makhawan watershed, using morphometry
}

\author{
Mohd Yousuf Khanday ${ }^{1}$ Akram Javed ${ }^{2}$
}

Received: 1 December 2016/ Accepted: 13 February 2017/Published online: 7 March 2017

(c) The Author(s) 2017. This article is published with open access at Springerlink.com

\begin{abstract}
In order to understand the hydrological behavior of a catchment area, morphometric analysis of the drainage basin plays an important role to expresses the geology, geomorphology and structural antecedents. In the present study, morphometric analysis and its influence on hydrology were carried out in Makhawan watershed, Central India, using SRTM, remote sensing and GIS. SRTM data were used for preparation of DEM, slope and aspect maps. DEM was used to delineate the watershed limits and to extract the channel network, which was later updated using IRS 1D LISS III data. The hydrological module in ArcGIS was used for calculation of watershed and morphometric parameters, under linear, relief and aerial aspects. The watershed shows dendritic-to-sub-dendritic drainage pattern; however, parallel-to-sub-parallel pattern developed locally which may be due to rejuvenation of streams in mature stage with moderate drainage texture. High drainage density in the watershed is observed over impermeable subsurface material, sparse vegetation with high relief; whereas, low drainage density is found over permeable subsurface material and low relief. It has been found that low relief with low drainage density areas are favorable sites for more groundwater prospects.
\end{abstract}

Keywords Morphometry · Hydrogeology · Watershed . Remote sensing $\cdot$ SRTM

Mohd Yousuf Khanday

ykhanday@gmail.com

1 Geological Survey of India, SU: J\&K, NR, Jammu 180006, India

2 Aligarh Muslim University, Aligarh 202002, India

\section{Introduction}

Increasing population pressure and climate change along with erratic rainfall have made water management plans quite difficult. Therefore, it is a need of hour to evaluate the water resources, because they play an utmost important role in sustainability of livelihood. Many river basins and sub-basins in different parts of the globe have been studied in detail using conventional methods for drainage network characteristics (Horton 1945; Strahler 1952, 1957, 1964; Leopold and Miller 1956; Morisawa 1959; Krishnamurthy et al. 1996). Drainage basins/catchments are the fundamental units of the fluvial landscape and the recent research has been carried out extensively on their geometric characteristics, topology of the stream networks, quantitative measurements of drainage texture, pattern, shape and relief aspects. The features of basin morphometry have been used to predict or describe geomorphic processes and estimation of sediment yields rates (Baumgardner 1987). Morphometry is the measurement and mathematical analyses of the configuration of the earth's surface, shape and dimension of its landforms (Agarwal 1998; Reddy et al. 2002).

For proper understanding of the nature of drainage basin, one has to prepare a drainage map and then compute the drainage morphometric parameters (Krishnamurthy et al. 1996; Kumar et al. 2000; Reddy et al. 2002; Nag and Chakraborty 2003; Nooka Ratnam et al. 2005). The primary factors responsible for running water ecosystem functioning in a particular basin are climate, geology, relief, soils and vegetation (Lotspeich and Platts 1982; Frissel et al. 1986; Mesa 2006). The influence of drainage morphometry on landform characteristics can be well understood by the analysis of morphometric parameters of watershed (Sreedevi et al. 2009). Identification of drainage networks within watershed and subwatersheds can be

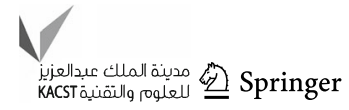


achieved using topographic maps or alternatively with advanced methods using remote sensing and DEMs (Verstappen 1983; Mark 1983; O'Callaghan and Mark 1984; Rinaldo et al. 1998; Macka 2001; Maidment 2002). Topographic maps have been widely used to describe the geomorphology of drainage networks (Schumm 1956; Mark 1983); however, they do not represent the real drainage networks on the ground due to cartographic generalizations and subjective judgment of the cartographers (Chorley and Dale 1972; Drummond 1974; Mark 1983). Furthermore, there are often numerous valleys, which are not cartographically marked as fluvial channels despite their ability to collect and transport flow. For these reasons, the first-order streams called "fingertip" by Horton (1945) or "exterior links" by Shreve (1966) and Tarboton et al. (1991) should be included in drainage network studies. Many authors pointed out this in their studies (Horton 1945; Melton 1957; Lubowe 1964; Krumbein and Shreve 1970; Mark 1983; Javed et al. 2009; Khanday and Javed 2016). Because of this, an attempt has been made in the present study to use remote sensing and SRTM data for updating these fingertip drainages. Singh et al. $(2013,2014)$ have carried out morphometric analysis of Morar River Basin, Madhya Pradesh, India, and hydrological inferences from watershed analysis for water resource management, using remote sensing and GIS techniques.

The study area falls under semi-arid climatic conditions and receives recharge mainly through rainfall and the area needs morphometric analysis to understand the physiographic status of the area. Agriculture is the prime occupation of the local community though the surface water resources are limited; hence, irrigation is mostly dependent on groundwater resources. Due to the increasing population and unpredictable change in rainfall pattern, water level has gone down to deeper levels. This calls for sustainable development of watershed in terms of surface and ground water resources in this area. For carrying out such studies, it becomes necessary to know the drainage characteristics, erosion status and topography of the region to formulate a comprehensive watershed development plan. For morphometric analysis using topographic maps, remote sensing, SRTM data and GIS techniques are speedy, precise, fast and less expensive (Farr and Kobrick 2000; Grohmann et al. 2007). The main aim of the present study is to delineate and analyze various parameters of a drainage network at watershed/subwatershed level using topographic maps, SRTM data and GIS techniques to know the geometry of the basin for hydrological conditions. The results obtained may be the scientific database for further detailed hydrological investigations in such areas.

\section{Study area description}

Makhawan watershed is situated in the north-western part of Guna district of Madhya Pradesh (Central India), includes main headquarter Guna in the southern part of the watershed. The watershed occupies an area of $163.30 \mathrm{~km}^{2}$, and lies between geographical coordinates $77^{\circ} 14^{\prime} 15^{\prime \prime}$ $77^{\circ} 22^{\prime} 27^{\prime \prime}$ East longitudes and $24^{\circ} 36^{\prime} 50^{\prime \prime}-24^{\circ} 45^{\prime} 32^{\prime \prime}$ North latitudes corresponding to toposheets $54 \mathrm{H} / 2,54 \mathrm{H} / 5$ and 54H/6 (Fig. 1). The maximum and minimum elevation found in the watershed is 529 and $438 \mathrm{~m}$ above mean sea level (MSL), respectively (Fig. 2), in which the darker shades show higher elevations; whereas, lighter shades depict lower elevation. The area is connected with AgraBombay Highway (NH-3) and Western Railway's broad gauge line of the Kota-Bina section, which provides all communications with other states. The main Makhawan River flows almost southeast to northwest, indicating a general slope towards northwest. A check dam built on the Makhawan River in the central part of the watershed, primarily serves as an irrigation source for adjacent agricultural fields. In other parts of the watershed agriculture is mainly rain fed. There are eight villages falling within the watershed besides the main Guan city. The main crops grown are soyabean, paddy and groundnut in the Kharif season; whereas, wheat and gram are grown in Rabi season. Based on the Thornthwaite system of climate classification, the study area forms a part of semi-arid climatic zone and experiences a dry weather, with an average annual rainfall of about $821 \mathrm{~mm}$. The maximum temperature rises up to $45^{\circ} \mathrm{C}$ in June while minimum temperature can be as low as $7.9^{\circ} \mathrm{C}$ in January (Khanday and Javed 2008). The relative humidity is generally high and maximum relative humidity ( $88 \%$ ) is observed during the month of August. Summer remains the driest part of the year with humidity as low as $27 \%$ or even less during the month of April. The average annual humidity is about $61 \%$ (Singh et al. 2002).

\section{Drainage}

The drainage network of the watershed is primarily defined by Makhawan River and its tributaries. The pattern is dendritic to sub-dendritic; however, parallel-to-sub-parallel pattern has also developed locally. Based on the contour value, slope, relief, DEM and drainage network, the Makhawan watershed has been demarcated into seven subwatersheds which were designated as SW1-SW7. Total number of streams of all orders are 732, out of which 534 are of 1 st order, 150 are of 2 nd order, 40 are of 3rd order, 7 are of 4 th order and only one stream is of 5 th order. Out of seven subwatersheds, only one subwatershed (SW7) is of 

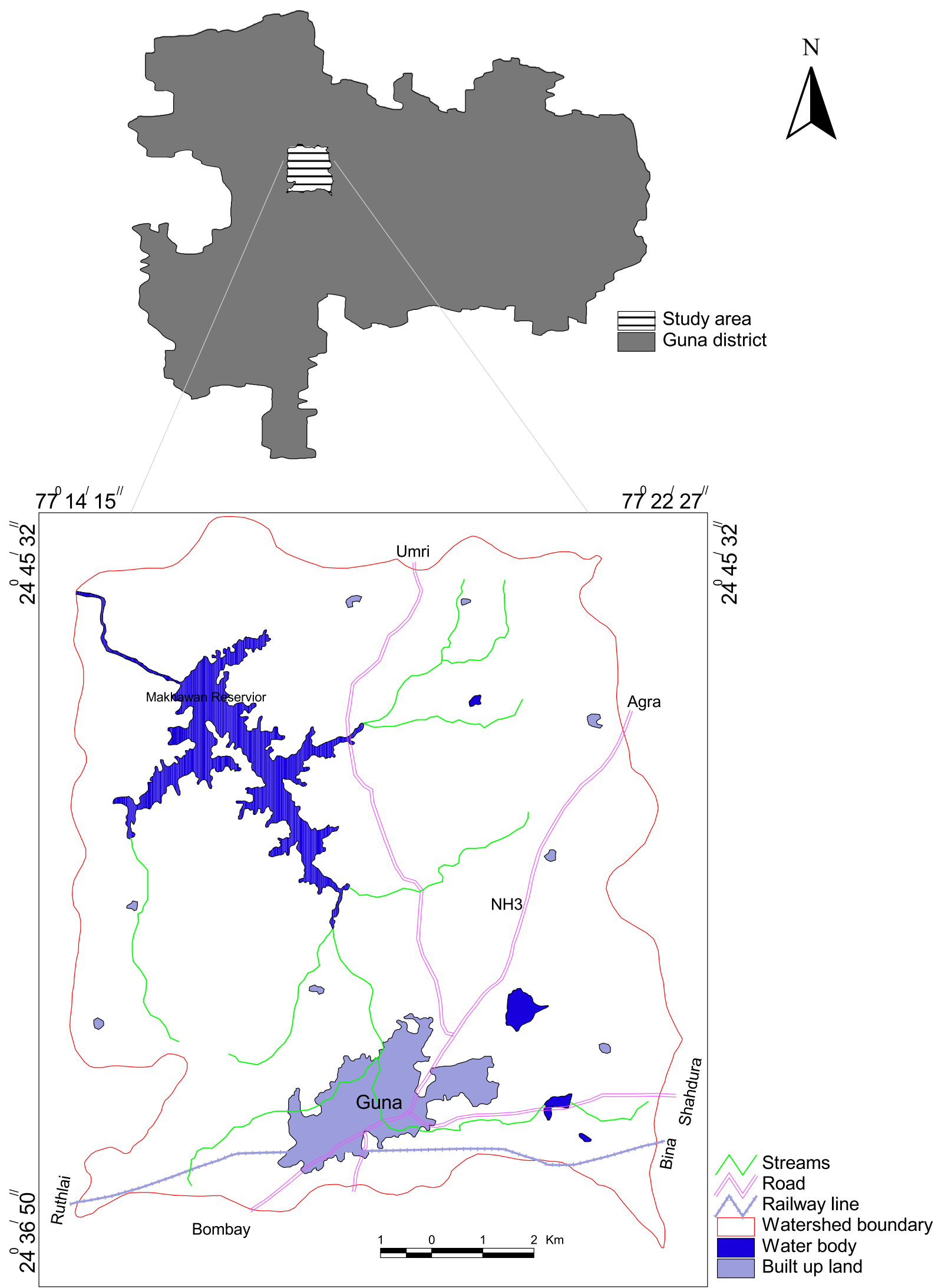

Fig. 1 Location map of the Makhawan watershed

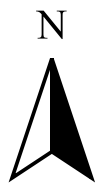




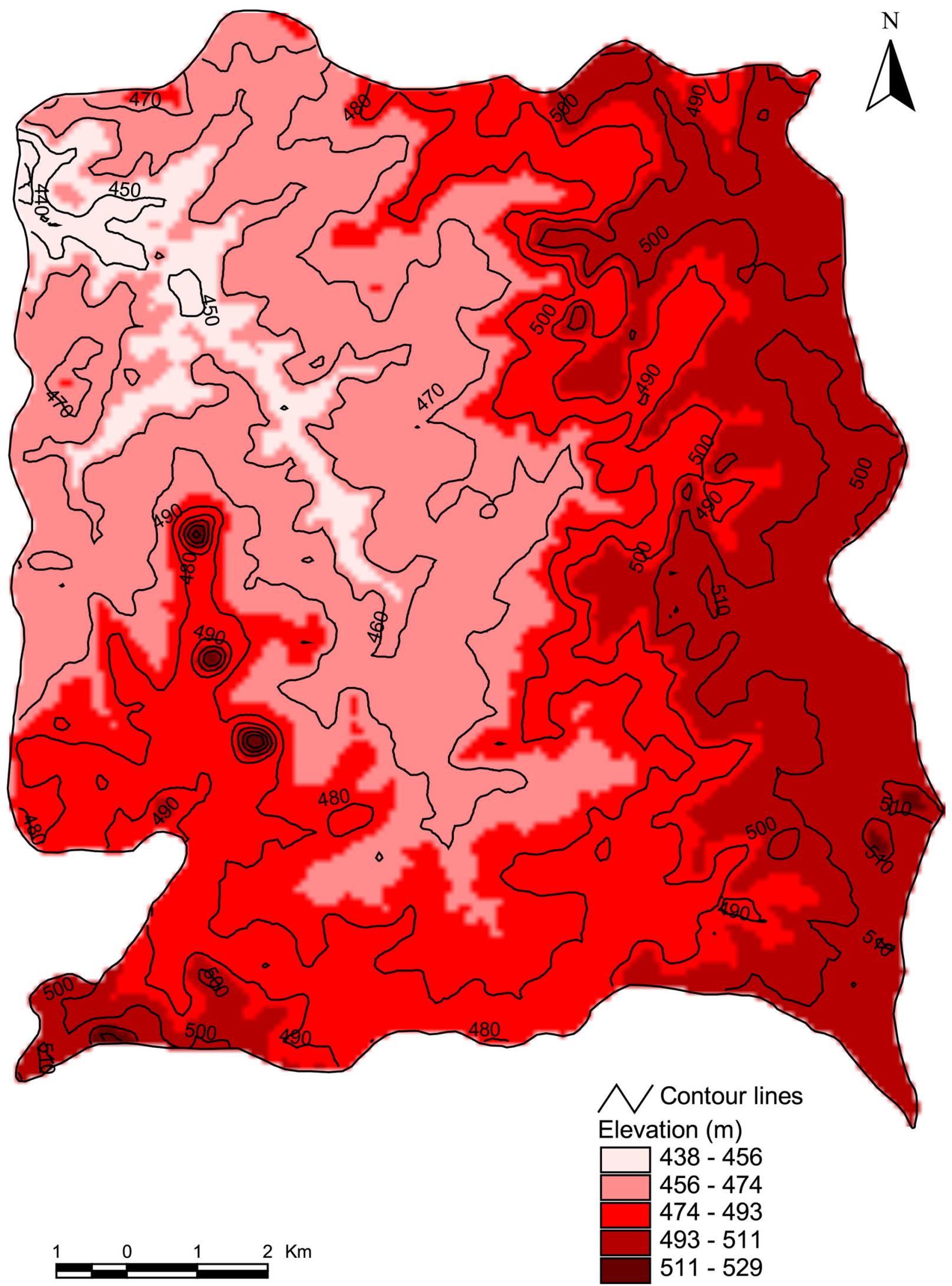

Fig. 2 Digital Elevation Model (DEM) of the Makhawan watershed derived from SRTM data 
5 th order; whereas, rest of the subwatersheds is of 4th order. The whole Makhawan watershed is also of 5th order (Fig. 3). 1st and 2nd order streams are associated with relatively higher elevations where relief and slope are high resulting in more runoff, and less recharge.

\section{Geomorphology}

The expression of surface and subsurface lithological and structural features, resulting in landforms has important control over the occurrence of natural resources. The study area has three geomorphic units, viz., Deccan Plateau, denudational hills and alluvial plain (Fig. 4). Deccan Plateau is the dominant geomorphic unit in the area. From the field observation denudational hills are composed of volcanic rocks of Deccan Traps which are highly jointed and fractured having high relief and steep slopes characterized by parallel-to-sub-parallel drainage pattern, high drainage density. Deccan plateau is composed of basalts of Deccan Traps which are fractured and jointed having undulated topography with dendritic-to-sub-dendritic drainage pattern, low-to-moderate drainage density; whereas, alluvial plains constitute gravel, sand silt and clay-sized unconsolidated material over a flat land surface, illustrated by low drainage density with high infiltration rate.

\section{Geology}

The study area is underlain by basaltic lava flows of Deccan Traps which predominantly belong to "simple" and "aa" type. The simple type consists of massive basalt, vesicular and zeolitic basalt; whereas, the "aa" type has massive and vesicular units except with highly fragmented top horizons. It is formed due to out-pouring of enormous lava flows at the end of the Mesozoic era which was spread over vast areas and flows piled up one over the other (Deshpande 1998). The flows are horizontal-to-subhorizontally bedded, very hard and are greenish gray in color. The laterite occurs on the top of basaltic lava flows, as disconnected patches of capping on hillocks. The top of the laterite is hard, red-colored rock followed by clayey zone and leached-out silica in the form of chert. Alluvium consists of finer siliceous debris washed away from the hills, composed of fine-to-coarse grained gravel, sand, silt, clay and kankar, yellowish brown and clayey loam, containing kankar nodules. Alluvium has predominant land use for cultivation, which is found along the course/plains of major streams (Fig. 5).

\section{Hydrogeology}

The area is mostly covered with basaltic flows of Deccan Traps followed by laterite and some deposits of recent alluvium along the main river course. Groundwater occurs in the area under phreatic and semi-confined-to-confined conditions. Lava flows of the Deccan Traps occupy $>70 \%$ of the area, in which weathered, jointed and fractured basalts form aquifers at different depths. The aquifers are being tapped through boreholes and dugwells. The depth to water level ranges from 2 to $13.16 \mathrm{mbgl}$ (meter below ground level) with seasonal fluctuation of $0-6.28 \mathrm{~m}$. The yield of aquifers mostly depends on the degree of weathering and fracturing, ranging from 1 to 5 lps (liter per second). However, in laterite and alluvium groundwater occurs under water table conditions. The granular portions of these formations such as sand and gravel form good aquifers. However, these have a limited areal extent confined to the banks of the main Makhawan River. The depth to water table ranges from 3.84 to $18.94 \mathrm{mbgl}$ with seasonal fluctuation of $1.54-6.50 \mathrm{~m}$ in areas underlain by alluvium and laterite.

\section{Slope}

For hydrological investigations, slope plays an important role which is governed by geomorphic processes having different lithological resistances (Sreedevi et al. 2005). The recent widespread availability of digital terrain data has made automatic procedures for topographic analyses popular. Therefore, in the present study SRTM data have been imported into ArcGIS software for deriving slope and aspect grids. Normally a slope map or aspect map displays the attribute values over areas such as regions instead of at points, such that within each area, all slopes fall into a certain range or all aspects fall into a certain quadrant. Aspect grid is defined as the down-slope direction of the maximum rate of change of a cell to its neighbors. This can be used to identify the orientation or direction of a hillside. The cell values in an aspect grid range from $0^{\circ}$ to $360^{\circ}$ (Fig. 6), in which $0^{\circ}$ is North in a clockwise direction, $90^{\circ}$ is east, $180^{\circ}$ is south, and $270^{\circ}$ is west (Gorokhovich and Voustianiouk 2006). Slope grid has been prepared following the methodology given by Burrough (1986) which identifies slope as the maximum rate of change between a cell and its neighbors. It is classified as a vector; since it has a quantity in terms of gradient as well as direction in the form of aspect. The output slope grid of Makhawan watershed contains values representing degree of slope from $0^{\circ}$ to $11^{\circ}$, with a mean slope of $1.10^{\circ}$ and slope standard deviation is $0.16^{\circ}$. For infiltration of groundwater into the subsurface and certain possibility of groundwater prospects, slope forms the main factor. Higher slope means high runoff which allows less residence time for rainwater; whereas, gentler slope means low surface runoff, which in turn allows more time for the rainwater to percolate and hence comparatively more infiltration (Sarkar et al. 2001). 


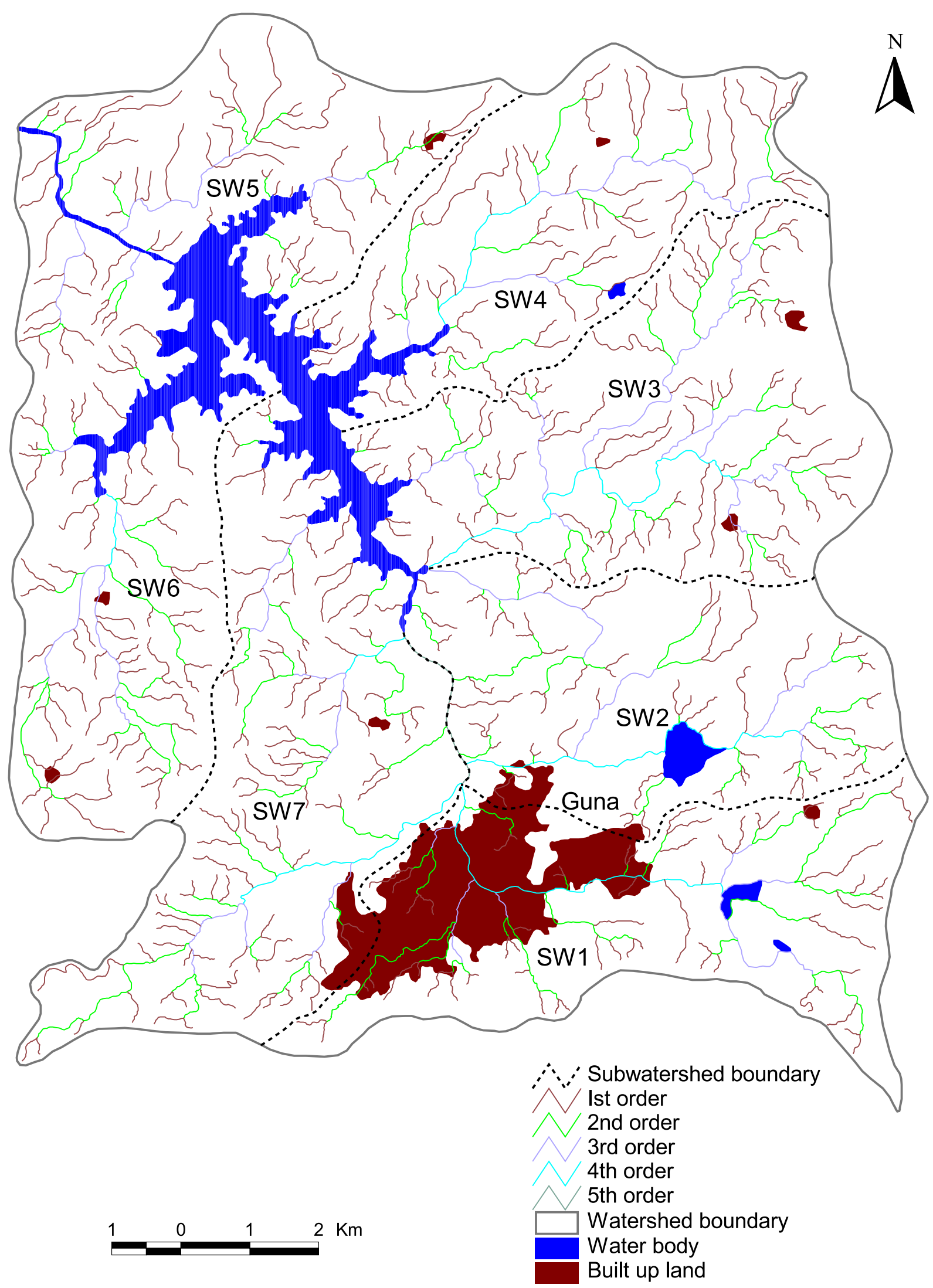

Fig. 3 Drainage network of the Makhawan watershed 


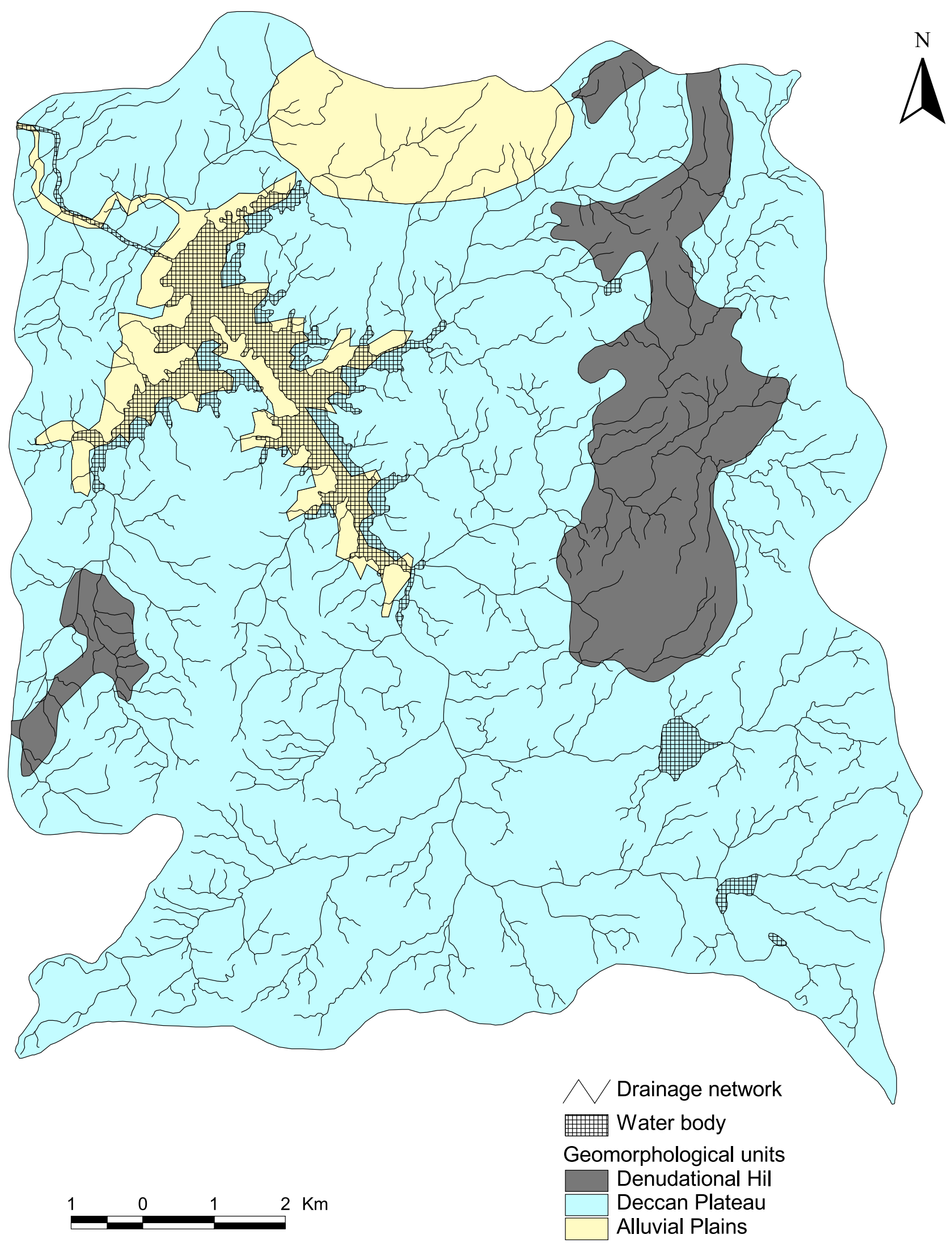

Fig. 4 Geomorphological units of the Makhawan watershed 


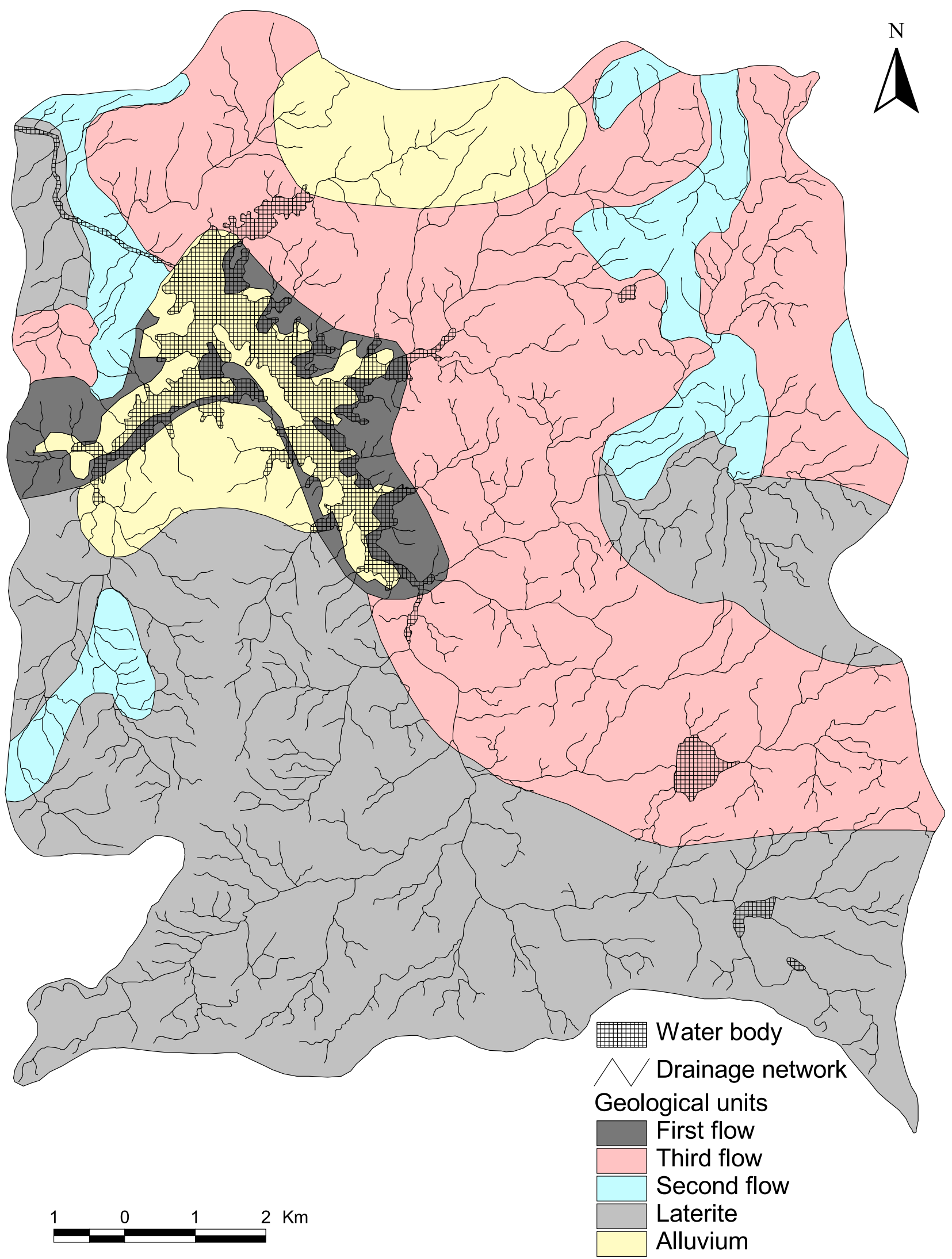

Fig. 5 Geology of the Makhawan watershed 


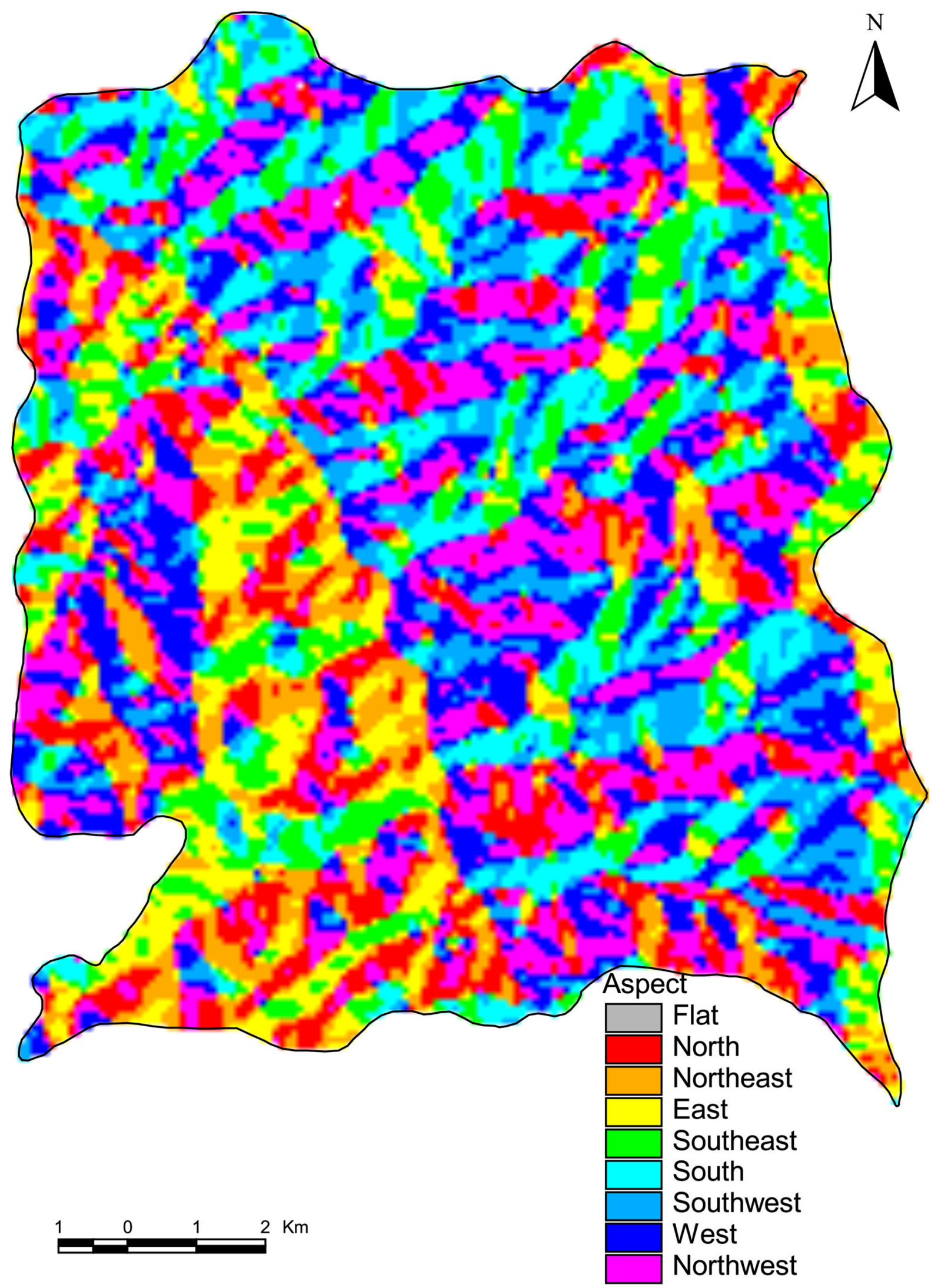

Fig. 6 Aspect map of the Makhawan watershed derived from SRTM data 
The higher degrees of slope are observed in the northeastern, south-eastern and south-western parts of the watershed (Fig. 7).

\section{Data used}

Survey of India (SOI) topographic sheets $54 \mathrm{H} / 2,54 \mathrm{H} / 5$ and $54 \mathrm{H} / 7$ on $1: 50,000$ scale, surveyed in 1982-1983, were utilized for base map preparation. Standard Geocoded False Color Composite (FCC) of Indian Remote Sensing satellite (IRS-1D) LISS III (Path-Row: 97-54) of 27th February, 2011, having a spatial resolution of $23.5 \mathrm{~m}$ of band combinations 2 (green), 3 (red) and 4 (near infrared) was procured from National Remote Sensing Center (NRSC), Hyderabad. Shuttle Radar Topography Mission (SRTM) data of $90 \mathrm{~m}$ resolution were downloaded from the website (http://www.srtm.csi.cgiar.org) for generating Digital Elevation Model (DEM), slope and aspect maps of the study area. Besides, the secondary information/data were collected and utilized wherever required, including published research papers, technical reports, special volumes and memoirs of the Geological Society of India, and information from other government and non-government sources were consulted. Limited ground truth verification was also carried out in key areas.

\section{Methodology}

\section{Geo-referencing}

The drainage map was originally derived from SOI toposheets and later updated with satellite data. Topographical maps were rectified/referenced geographically and the entire study area was delineated in GIS environment with the help of ArcGIS 10.2.1 software assigning Universal Transverse Mercator (UTM), World Geodetic System (WGS dating from 1984 and last revised in 2004) and $43 \mathrm{~N}$ Zone Projection System. SRTM data have also been converted into UTM projection. For geo-referencing, the latitudes and longitudes of a reference map were converted into $X, Y$ coordinates, and the corresponding $X$, $Y$ coordinates were put on the scanned map.

\section{Data generation}

The elevation value being the basic requirement for delineation of watershed, and is given the highest priority for the demarcation of watershed/subwatershed boundaries, which involved deriving information on drainage network first-order stream onwards (Dwivedi et al. 2006). The watershed boundaries were demarcated on the basis of contour value, slope, relief, and drainage flow directions and DEM. The SRTM data imported in the ArcGIS software, slope, aspect and topographic elevation maps were prepared with contours of the watershed.

In this research, the vector layer of drainage network was digitized in GIS environment. Drainage information was derived from SOI toposheet. Natural drainage system network present in SOI topographic sheet were digitized and later updated using DEM and FCC obtained from IRS LISS III satellite data in spatial analysis toolbox of ArcGIS environment. Subwatershed boundaries were drawn based on water divide line, obtained from watershed raster layer derived. Raster-to-vector conversion was carried out using the module available in ArcGIS and drainage was created as line coverage, assigning unique ids for various stream orders (1st order, 2nd order, 3rd order and so on). An integrated use of multispectral satellite data, DEM and Survey of India topographical sheets were utilized for generation of database and extraction of various drainage parameters such as stream number $(\mathrm{Nu})$, stream order $(u)$, cumulative stream length (Luc), mean stream length (Lsm), stream length (Lb), basin area (A), bifurcation ratio $(\mathrm{Rb})$, drainage density (D), stream frequency (Fs), drainage texture (Rt), relief ratio $(\mathrm{Rh})$, sinuosity index $(\mathrm{Si})$, basin shape (Bs), form factor (Rf), circularity ratio $(\mathrm{Rc})$, and elongation ratio $(\mathrm{Re})$ were computed at subwatershed level using standard methods and formulae (Horton 1932, 1945; Miller 1953; Schumm 1956; Hadely and Schumm 1961; Strahler 1957, 1964; Chopra et al. 2005; Nooka Ratnam et al. 2005; Solanke et al. 2005; Mesa 2006; Sreedevi et al. 2005, 2009). The input values such as area of the watershed, perimeter, maximum basin length, difference in relief, etc., were computed in ArcGIS using vector layer.

\section{Results and discussion}

The DEM with a pixel size (resolution) of $90 / 90 \mathrm{~m}$ of the study area has been used to generate slope and aspect maps. The study of drainage parameters plays a vital role in watershed management and planning irrigation and industrial development of an area (Javed 1995). Drainage development is controlled by climate, rainfall, lithology, slope, topography apart from exogenic and endogenic forces of the area (Melton 1957). Drainage order has inferred that Makhawan watershed is a 5th order watershed. The morphometric parameters have been computed under linear, relief and aerial aspects. Linear aspects include stream number, stream order, stream length, mean stream length, stream length ratio and bifurcation ratio. Relief aspects consist of relief, relief ratio, sinuosity index; whereas, aerial aspects include drainage density, stream frequency, drainage texture, form factor, circularity ratio, elongation ratio, basin shape. Quantitative assessment of 


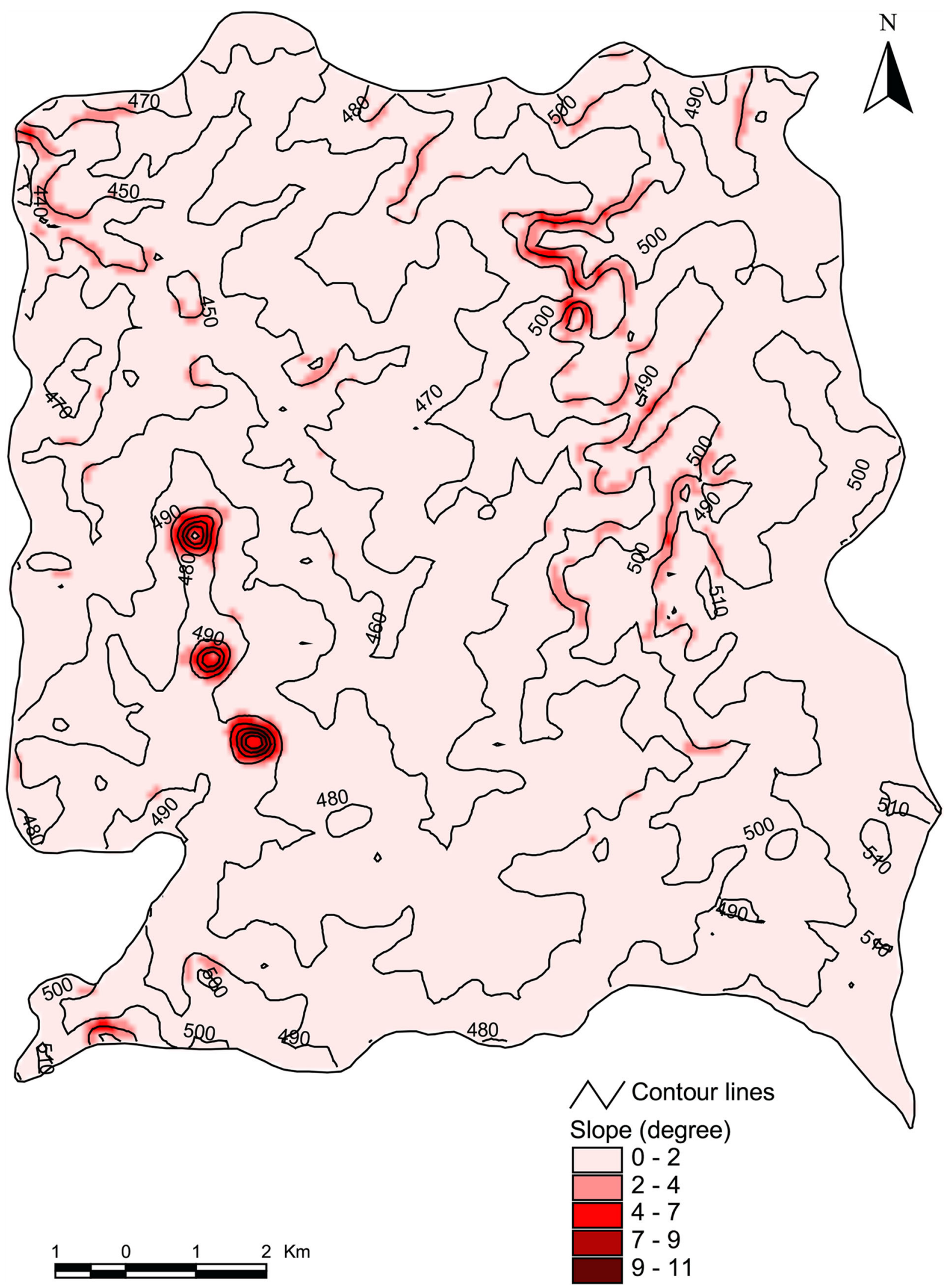

Fig. 7 Slope map of the Makhawan watershed derived from SRTM data 
Table 1 Morphometric parameters and their formulae

\begin{tabular}{|c|c|c|}
\hline Morphometric parameters & Formula & References \\
\hline Stream order $(u)$ & Hierarchical rank & Strahler (1964) \\
\hline Stream length $(\mathrm{Lu})$ & Length of streams & Horton (1945) \\
\hline Mean stream length (Lsm) & $\begin{array}{l}\mathrm{Lsm}=\mathrm{Lu} / \mathrm{Nu}, \text { where } \mathrm{Lsm}=\text { mean stream length, } \mathrm{Lu}=\text { total stream } \\
\text { length of order ' } u \text { ', } \mathrm{Nu}=\text { total no. of streams segments of order ' } u \text { ' }\end{array}$ & Strahler (1964) \\
\hline Stream length ratio $(\mathrm{RL})$ & $\begin{array}{l}\mathrm{RL}=\mathrm{Lu} / \mathrm{Lu} 1 \text {, where } \mathrm{RL}=\text { stream length ratio, } \mathrm{Lu}=\text { total stream } \\
\text { length of order ' } u \text { ', } \mathrm{Lu} 1=\text { total stream length of its next lower } \\
\text { order }\end{array}$ & Horton (1945) \\
\hline Bifurcation ratio $(\mathrm{Rb})$ & $\begin{array}{l}\mathrm{Rb}=\mathrm{Nu} / \mathrm{Nu} 1, \text { where } \mathrm{Rb}=\text { bifurcation ratio, } \mathrm{Nu}=\text { total no. of } \\
\text { stream segments of order ' } u \text { ', Nu1 = no. of segments of the next } \\
\text { higher order }\end{array}$ & Schumm (1956) \\
\hline Mean bifurcation ratio (Rbm) & $\mathrm{Rbm}=$ average of bifurcation ratios of all orders & Strahler(1957) \\
\hline Relief ratio $(\mathrm{Rh})$ & $\begin{array}{l}\mathrm{Rh}=H / \mathrm{Lb} \text {, where } \mathrm{Rh}=\text { relief ratio, } H=\text { total relief (relative relief) } \\
\text { of the basin kilometer, } \mathrm{Lb}=\text { basin length }\end{array}$ & Schumm (1956) \\
\hline Sinuosity index $(\mathrm{Si})$ & $\mathrm{Si}=(X / \mathrm{Lb})$, where $X=$ average drainage length, $\mathrm{Lb}=$ basin length & Leopold et al. (1964) \\
\hline Drainage density $(D)$ & $\begin{array}{l}D=\mathrm{Lu} / A, \text { where } D=\text { drainage density, } \mathrm{Lu}=\text { total stream length of } \\
\text { all orders, } A=\text { area of the basin }\left(\mathrm{km}^{2}\right)\end{array}$ & Horton (1932) \\
\hline Stream frequency $(\mathrm{Fs})$ & $\begin{array}{l}\mathrm{Fs}=\mathrm{Nu} / A, \text { where } \mathrm{Fs}=\text { stream frequency, } \mathrm{Nu}=\text { total no. of streams } \\
\text { of all orders, } A=\text { area of the basin }\left(\mathrm{km}^{2}\right)\end{array}$ & Horton (1932) \\
\hline Drainage texture $(\mathrm{Rt})$ & $\begin{array}{l}\mathrm{Rt}=\mathrm{Nu} / P \text {, where } \mathrm{Rt}=\text { drainage texture, } \mathrm{Nu}=\text { total no. of streams } \\
\text { of all orders, } P=\text { perimeter of the basin }(\mathrm{km})\end{array}$ & Horton (1945) \\
\hline Form factor (Rf) & $\begin{array}{l}\mathrm{Rf}=A / \mathrm{Lb}^{2}, \text { where } \mathrm{Rf}=\text { form factor, } A=\text { area of the basin }\left(\mathrm{km}^{2}\right) \\
\mathrm{Lb}^{2}=\text { square of the basin length }\end{array}$ & Horton (1932) \\
\hline Circularity ratio (Rc) & $\begin{array}{l}\mathrm{Rc}=12.57 A / P^{2}, \text { where } \mathrm{Rc}=\text { circularity ratio, } A=\text { area of the basin } \\
\quad\left(\mathrm{km}^{2}\right), P^{2}=\text { perimeter }(\mathrm{km})\end{array}$ & Miller (1953) \\
\hline Elongation ratio $(\mathrm{Re})$ & $\begin{array}{l}\mathrm{Re}=(2 / \mathrm{Lb}) \times \sqrt{ }(A / P), \text { where } \mathrm{Re}=\text { elongation ratio, } A=\text { area of } \\
\text { the basin }\left(\mathrm{km}^{2}\right), \mathrm{Lb}=\text { basin length }\end{array}$ & Schumm (1956) \\
\hline Basin shape (Bs) & $\mathrm{Bs}=\mathrm{Lb}^{2} / A$ & Horton (1945) \\
\hline
\end{tabular}

these parameters has been carried out using standard mathematical formulae (Table 1).

\section{Linear aspects}

According to Horton (1945) and later modified by Strahler (1964), designation of stream orders is the first step in drainage basin analysis based on ranking of streams. The firstorder streams have no tributaries; the second-order streams have only first-order streams as tributaries. Similarly, the third-order streams have first and second-order streams as tributaries and so on. The trunk stream through which entire discharge of water passes is the stream of the highest order (Chopra et al. 2005). The stream ordering of the watershed suggested that the Makhawan watershed is of fifth order. Six subwatersheds (SW1-SW6) are of fourth order; however, SW7 is of fifth order. In SW3, SW6 and SW7 1st and 2nd order steams are dominant since these subwatersheds possess moderate-to-steep slope and similar relief features.

Stream length of various orders, has been measured using vector layer in.dbf format in ArcGIS software. After adding stream length of each stream for a given order $(u)$, total stream length $(\mathrm{Lu})$ of each order was computed. Total length of streams of all orders in the watershed is $472.74 \mathrm{~km}$, whereas SW1-SW7, the stream lengths are 57.4, 58.14, 82.94, 68.2, 49.95, 78.33 and $90.4 \mathrm{~km}$, respectively (Table 2 ).

The mean stream length (Lsm) is computed by dividing the total stream length of order "Lu" by the number of stream segments of order "Nu" (Srinivasa et al. 2004). As a thumb rule, mean length of channel segments of a given order is greater than that of the next lower order but less than the next higher order. Lsm values of the subwatersheds vary from 0.41 (SW1) to 12.92 (SW6) indicating that SW5 at 2nd order shows an anomaly which might be due to variation in slope and topography.

The stream length ratio (RL) between streams of different orders shows variation (Table 2), which may be due to variation in slope and topography. SW2, SW4, SW6 and SW7 show an increasing trend in stream length ratio from lower order to higher order showing mature geomorphic stage. But in SW1, SW3 and SW5, RL values show difference from one order to another order which indicate their late youth stage of geomorphic development, suggesting an important relationship with runoff and erosional status of the watershed. 
Table 2 Stream analysis of the subwatersheds and the whole Makhawan watershed

\begin{tabular}{|c|c|c|c|c|c|}
\hline \multirow[t]{2}{*}{ Subwatersheds } & \multicolumn{5}{|c|}{ Stream order } \\
\hline & $1 \mathrm{st}$ & 2nd & $3 \mathrm{rd}$ & 4 th & 5 th \\
\hline \multicolumn{6}{|l|}{$S W 1$} \\
\hline No. of streams & 62 & 20 & 6 & 1 & - \\
\hline Stream length $(\mathrm{km})$ & 25.69 & 19.43 & 6.79 & 5.49 & - \\
\hline Cumulative stream length $(\mathrm{km})$ & 25.69 & 45.12 & 51.91 & 57.40 & - \\
\hline Mean stream length $(\mathrm{km})$ & 0.41 & 0.97 & 1.13 & 5.49 & \\
\hline \multicolumn{6}{|l|}{$S W 2$} \\
\hline No. of streams & 66 & 21 & 5 & 1 & - \\
\hline Stream length $(\mathrm{km})$ & 27.26 & 12.61 & 8.94 & 9.33 & - \\
\hline Cumulative stream length (km) & 27.26 & 39.87 & 48.81 & 58.14 & - \\
\hline Mean stream length $(\mathrm{km})$ & 0.41 & 0.60 & 1.79 & 9.33 & \\
\hline \multicolumn{6}{|l|}{ SW3 } \\
\hline No. of streams & 99 & 28 & 9 & 1 & - \\
\hline Stream length $(\mathrm{km})$ & 45.45 & 13.58 & 13.30 & 10.61 & - \\
\hline Cumulative stream length (km) & 45.45 & 59.03 & 72.33 & 82.94 & - \\
\hline Mean stream length (km) & 0.46 & 0.49 & 1.48 & 10.61 & \\
\hline \multicolumn{6}{|l|}{ SW4 } \\
\hline No. of streams & 65 & 17 & 5 & 1 & - \\
\hline Stream length $(\mathrm{km})$ & 39.64 & 12.69 & 7.91 & 7.96 & - \\
\hline Cumulative stream length (km) & 39.64 & 52.33 & 60.24 & 68.20 & - \\
\hline Mean stream length $(\mathrm{km})$ & 0.61 & 0.75 & 1.58 & 7.96 & \\
\hline \multicolumn{6}{|l|}{ SW5 } \\
\hline No. of streams & 52 & 15 & 3 & 1 & - \\
\hline Stream length $(\mathrm{km})$ & 27.50 & 6.82 & 8.29 & 7.34 & - \\
\hline Cumulative stream length $(\mathrm{km})$ & 27.50 & 34.32 & 42.61 & 49.95 & - \\
\hline Mean stream length (km) & 0.53 & 0.45 & 2.76 & 7.34 & \\
\hline \multicolumn{6}{|l|}{ SW6 } \\
\hline No. of streams & 87 & 21 & 6 & 1 & - \\
\hline Stream length $(\mathrm{km})$ & 44.47 & 13.30 & 7.64 & 12.92 & - \\
\hline Cumulative stream length $(\mathrm{km})$ & 44.47 & 57.77 & 65.41 & 78.33 & - \\
\hline Mean stream length $(\mathrm{km})$ & 0.51 & 0.63 & 1.27 & 12.92 & \\
\hline \multicolumn{6}{|l|}{ SW7 } \\
\hline No. of streams & 103 & 28 & 6 & 2 & 1 \\
\hline Stream length $(\mathrm{km})$ & 45.01 & 19.59 & 8.12 & 7.74 & 9.94 \\
\hline Cumulative stream length $(\mathrm{km})$ & 45.01 & 64.60 & 72.72 & 80.46 & 90.40 \\
\hline Mean stream length $(\mathrm{km})$ & 0.44 & 0.70 & 1.35 & 3.87 & 9.94 \\
\hline \multicolumn{6}{|l|}{ Whole Makhawan watershed } \\
\hline No. of streams & 534 & 150 & 40 & 7 & 1 \\
\hline Stream length $(\mathrm{km})$ & 255.02 & 98.02 & 60.99 & 26.81 & 31.90 \\
\hline Cumulative stream length $(\mathrm{km})$ & 255.02 & 353.04 & 414.03 & 440.84 & 472.74 \\
\hline Mean stream length (km) & 0.48 & 0.65 & 1.52 & 3.83 & 31.90 \\
\hline
\end{tabular}

Bifurcation ratios characteristically range between 3.0 and 5.0 for watersheds in which the geologic structures do not distort the drainage pattern. Bifurcation ratio $(\mathrm{Rb})$ values in the study area vary from 1.00 to 9.00 . Higher $\mathrm{Rb}$ values in SW1 (3rd/4th order), SW2 (3rd/4th order), SW3 (3rd/4th order), SW4 (3rd/4th order), SW5 (2nd/3rd order) and SW6 (3rd/4th order), indicate structural control on the drainage pattern; whereas, lower Rb values in SW7 is indicative of less structural control. The mean bifurcation ratio $(\mathrm{Rbm})$ values of the subwatersheds lie between 2.87 and 4.16 (Table 2) which belong to normal basin category (Strahler 1957). 


\section{Relief aspects}

Basin relief is one of the most important factors for understanding denudational processes operating in a basin (Chow 1964). The highest elevation encountered in the watershed is $530 \mathrm{~m}$ and the lowest is $438 \mathrm{~m}$, which indicates total relief of the basin as $92 \mathrm{~m}$. The $\mathrm{Rh}$ values in the watershed vary from 0.004 (SW1 and SW3) to 0.012 (SW7), higher values of Rh in SW7 indicate steep slope and high relief $\left(9^{\circ}-11^{\circ}\right)$ representing isolated hillocks; whereas, lower values in rest of the six subwatersheds may indicate presence of the Deccan plateau and alluvial plains with gentle slope and low relief. This indicates that SW7 has a high discharge capacity having poor indication of inadequate groundwater potential.

Sinuosity is the degree to which a river departs from a straight line (Schumm and Khan 1972). The distance between two points on the stream measured along the channel divided by the straight line distance between two points is termed as sinuosity ratio (Brice 1984; Ebisemiju 1994) and is used to determine whether a channel is straight or meandering. Sinuosity index $(\mathrm{Si})$, is the ratio between average channel length $(X)$ and basin length (Lb). A stream showing sinuosity index $>1.5$ may be treated as a meandering stream and $<1.5$ as non-meandering. However, if a stream at young stage shows $\mathrm{Si}>1.6$, it can be attributed to rejuvenation of stream. The Si values of the subwatersheds ranges from 1.42 (SW1) to 2.55 (SW3), indicating that subwatersheds may be treated as meandering streams except SW1 which is approaching to meandering because of its low value; whereas, Makhawan watershed has Si value of 5.16 which may be attributed to the phenomenon of rejuvenation.

\section{Aerial aspect}

Horton (1932) had introduced drainage density as an expression to indicate the closeness of spacing of channels. Langbein (1947) recognized the significance of drainage density as a factor determining the time of travel by water and suggested that drainage density values between 0.55 and $2.09 \mathrm{~km} / \mathrm{km}^{2}$ corresponding to humid regions. An area with high precipitation such as thundershowers loses greater percentage of rainfall as runoff resulting in more surface drainage channels. Density of vegetation and rainfall absorption capacity of soils, influence the rate of surface runoff and affects the drainage texture of an area (Gregory and Gardiner 1975; Gregory 1976; Montgomery and Dietrich 1989; Trucker and Bras 1998).

Drainage density $(D)$ values of the subwatersheds vary from 2.49 (SW1) to $3.28 \mathrm{~km} / \mathrm{km}^{2}$ (SW7) fall in low density category. SW1 and SW2 suggest permeable subsoil material and presence of vegetative cover; however, SW3, SW4,
SW5, SW6 and SW7 have relatively high drainage density, indicating less permeable material, sparse vegetative cover and moderate-to-high relief. The drainage density of the whole Makhawan watershed also falls in low category, i.e., $2.89 \mathrm{~km} / \mathrm{km}^{2}$ (Table 3).

Stream frequency (Fs) values of the subwatersheds vary from 3.87 (SW1) to 5.08 (SW7) and display a positive correlation with the drainage density values of the subwatersheds indicating an increase in stream population with respect to increase in drainage density except SW4, which shows relatively low stream frequency despite having a high drainage density. Fs reflects the drainage texture and mainly depends on the lithology of the watershed (Sreedevi et al. 2009).

Smith (1950) classified drainage density into five different classes of drainage texture, i.e., less than 2 indicates very coarse, between 2 and 4 is coarse, between 4 and 6 is moderate, between 6 and 8 is fine and greater than 8 is very fine drainage texture. The values of Rt vary from 3.12 (SW1) to 5.83 (SW3), out of which SW1, SW4 and SW5 show coarse drainage texture; whereas, SW2, SW3, SW6 and SW7 exhibit medium drainage texture (Table 3).

Horton (1932) defined form factor (Rf) as a dimensionless ratio of basin area $(A)$ to the square of basin length $(\mathrm{Lb})$. The value of form factor would always be less than 0.7854 (for a perfectly circular basin). Smaller the value of the form factor, more elongated will be the basin. The basins with higher values of form factors have high peak flows for shorter duration, whereas elongated basins with lower values of form factor have lower peak flow for longer duration. Flood flows of elongated basins with low form factor are easier to manage than those of the circular basins with higher values of form factor (Nautiyal 1994). The form factor (Rf) values vary from 0.25 (SW6) to 0.43 (SW2) indicating elongated shape with flatter peak flow for longer duration. Flood flows of such elongated basins are easier to manage.

Miller (1953) defined circularity ratio $(\mathrm{Rc})$, as the ratio of the area of the basin $(A)$ to the area of a circle having the same circumference as the perimeter of the basin $(P)$. The circularity ratio $(\mathrm{Rc})$ is influenced by the length and frequency of streams, geological structures, land use/land cover, climate, relief and slope of the basin (Chopra et al. 2005). The circularity ratio remained remarkably uniform in the range of 0.6-0.7 for first-order and second-order basins in homogeneous shales and dolomites, indicating the tendency of small drainage basins in homogeneous geologic materials to preserve geometrical similarity. However, first- and second-order basins situated on the flanks of moderately dipping strata are strongly elongated with circularity ratios between 0.4 and 0.5 (Chow 1964). The circularity ratio (Rc) ranges from 0.36 (SW1) to 0.67 (SW2), indicating elongated shape characterized by moderate-tohigh relief. 
Schumm (1956) defined elongation ratio $(\mathrm{Re})$ as the ratio between the diameter of the circle of the same area as the drainage basin $(A)$ and the maximum length of the basin $(\mathrm{Lb})$. The values can be grouped into three categories as circular $(>0.9)$, oval $(0.9-0.8)$ and less elongated $(<0.7)$. Values close to 1.0 are normally found in regions of very low relief, whereas values of 0.6-0.8 are usually associated with high relief and steep ground slope (Strahler 1964). A circular basin is more efficient in the discharge of runoff than an elongated basin (Singh and Singh 1997). Higher Re values show high infiltration capacity and low runoff; whereas, lower Re values are characterized by high susceptibility to erosion and sediment load. The values of elongation ratio $(\mathrm{Re})$ of the subwatersheds vary from 0.18 (SW1) to 0.29 (SW2); out of these subwatersheds SW2, SW3 and SW5 show higher Re values suggesting high infiltration capacity and low runoff, whereas subwatersheds SW1, SW4, SW6 and SW7 with lower Re values suggest susceptibility to erosion and sedimentation load (Khanday 2009).

Basin shape (Bs) verified that long narrow basins with high bifurcation ratios would be expected to have attenuated flood discharge periods, whereas rounded basins of low bifurcation ratio would be expected to have sharply peaked flood discharges (Chow 1964). Basin shape (Bs) values vary from 2.34 (SW2) to 4.41 (SW1) indicating that SW3 has weaker flood discharge periods and probability of more infiltration due to its higher bifurcation ratio, whereas rest of the six subwatersheds have sharply peaked flood discharge.

\section{Qualitative groundwater potential zones}

The quantitative analysis of morphometric parameters is found to be of immense utility in watershed delineation, soil and water conservation and their management. Since subsurface hydrological conditions of an area are controlled by the drainage characteristics of the basin, they play an important role in locating groundwater prospective areas (Pradhan 2009). Drainage pattern is the source of surface water and is dependent upon intrinsic characters of lithology, soil, depositional and structural features which have direct relationship with geomorphological setup of the area (Schumm 1956).

The present study area mainly depends on the rainfall to fulfill the requirements of local community for domestic as well as agricultural purposes, the scarcity of which could lead to acute water crisis resulting in severe drought

Table 3 Results of the morphometric analysis of the subwatersheds and whole Makhawan watershed

\begin{tabular}{|c|c|c|c|c|c|c|c|c|}
\hline Basin parameters & SW1 & SW2 & SW3 & SW4 & SW5 & SW6 & SW7 & $\begin{array}{l}\text { Whole Makhawan } \\
\text { watershed }\end{array}$ \\
\hline Basin area $(A)\left(\mathrm{km}^{2}\right)$ & 23.02 & 21.36 & 27.11 & 21.44 & 16.55 & 26.28 & 27.54 & 163.30 \\
\hline Bifurcation ratio $(\mathrm{Rb}) \mathrm{I} / \mathrm{II}$ & 3.10 & 3.14 & 3.54 & 3.82 & 3.47 & 4.14 & 3.68 & 3.56 \\
\hline Bifurcation ratio $(\mathrm{Rb}) \mathrm{II} / \mathrm{III}$ & 3.33 & 4.20 & 3.11 & 3.40 & 5.00 & 3.50 & 4.67 & 3.75 \\
\hline Bifurcation ratio $(\mathrm{Rb}) \mathrm{III} / \mathrm{IV}$ & 6.00 & 5.00 & 9.00 & 5.00 & 3.00 & 6.00 & 3.00 & 5.71 \\
\hline Bifurcation ratio $(\mathrm{Rb}) \mathrm{IV} / \mathrm{V}$ & 1.00 & 1.00 & 1.00 & 1.00 & 1.00 & 1.00 & 2.00 & 7.00 \\
\hline Bifurcation ratio $(\mathrm{Rb}) \mathrm{V} / \mathrm{VI}$ & & - & - & - & - & - & 1.00 & 1.00 \\
\hline Mean bifurcation ratio (Rbm) & 3.36 & 3.34 & 4.16 & 3.31 & 3.12 & 3.66 & 2.87 & 4.20 \\
\hline Stream length ratio (RL) II/I & 0.76 & 0.46 & 0.30 & 0.32 & 0.25 & 0.30 & 0.44 & 0.38 \\
\hline Stream length ratio (RL) III/II & 0.35 & 0.71 & 0.98 & 0.62 & 1.21 & 0.57 & 0.41 & 0.62 \\
\hline Stream length ratio (RL) IV/III & 0.81 & 1.40 & 0.80 & 1.01 & 0.89 & 1.69 & 0.95 & 0.44 \\
\hline Stream length ratio (RL) V/IV & - & - & - & - & - & - & 1.28 & 1.19 \\
\hline Perimeter $(P)(\mathrm{km})$ & 28.49 & 19.96 & 23.50 & 22.83 & 19.22 & 26.14 & 28.44 & 62.10 \\
\hline Basin length (Lb) (km) & 10.08 & 7.07 & 8.12 & 8.56 & 6.79 & 10.25 & 9.51 & 18.34 \\
\hline Basin width (Lw) (km) & 4.07 & 4.44 & 5.50 & 3.87 & 4.23 & 4.31 & 4.33 & 12.72 \\
\hline Drainage density $(D)\left(\mathrm{km} / \mathrm{km}^{2}\right)$ & 2.49 & 2.72 & 3.06 & 3.18 & 3.02 & 2.98 & 3.28 & 2.89 \\
\hline Stream frequency $(\mathrm{Fs})$ & 3.87 & 4.35 & 5.05 & 4.10 & 4.29 & 4.38 & 5.08 & 4.48 \\
\hline Relief ratio $(\mathrm{Rh})$ & 0.004 & 0.008 & 0.004 & 0.006 & 0.007 & 0.007 & 0.012 & 0.005 \\
\hline Sinuosity index (Si) & 1.42 & 2.06 & 2.55 & 1.99 & 1.84 & 1.91 & 1.90 & 5.16 \\
\hline Drainage texture (Rt) & 3.12 & 4.66 & 5.83 & 3.85 & 3.69 & 4.40 & 4.92 & 11.78 \\
\hline Basin shape (Bs) & 4.41 & 2.34 & 2.43 & 3.42 & 2.79 & 3.40 & 3.28 & 2.06 \\
\hline Form factor (Rf) & 0.27 & 0.43 & 0.41 & 0.29 & 0.36 & 0.25 & 0.30 & 0.49 \\
\hline Circularity ratio $(\mathrm{Rc})$ & 0.36 & 0.67 & 0.62 & 0.52 & 0.56 & 0.48 & 0.43 & 0.53 \\
\hline Elongation ratio $(\mathrm{Re})$ & 0.18 & 0.29 & 0.27 & 0.22 & 0.27 & 0.20 & 0.20 & 0.18 \\
\hline
\end{tabular}


conditions. The principal recharge of groundwater body in the area is through monsoon precipitation. The drainage pattern of the Makhawan watershed is dendritic to subdendritic due to homogenous lithology; however, parallelto-sub-parallel pattern has also developed locally confirming some structural control over drainage development. In the study area, high drainage density is observed over the hilly terrain (529-493 m amsl) with impermeable hard rock substratum, and low drainage density over the highly permeable sub-soils and low relief areas. Low drainage density areas are favorable for identification of groundwater potential zones. It has been observed in the field and from the analysis that the gentler slope has more prospects for groundwater. Slope and elevation maps revealed that moderate slopes $\left(4^{\circ}-7^{\circ}\right)$ where the elevation ranges from 474 to $493 \mathrm{~m}$ amsl towards central and north-western parts of the watershed, which are characterized by low drainage density and stream frequency form the recharge zone of the watershed since the surface drainage gets more time to infiltrate into the ground. This zone has less drainage density, thereby less runoff and more infiltration and is characterized by thick zone of weathered material; therefore, this zone is suitable for recharge structures.

\section{Conclusion}

The present study demonstrates the utility of remote sensing, SRTM and GIS in drainage delineation and their updation, which have been used for the morphometric analysis at subwatershed level. The drainage pattern of the area is dendritic to sub-dendritic in nature; however, parallel-to-sub-parallel pattern is also developed locally. Dendritic to sub-dendritic may be due to somewhat homogenous lithology and structural control which is reflected by higher values of bifurcation ratio, whereas parallel to sub-parallel may be due to the rejuvenation of streams in mature stage. Stream ordering of the watershed suggests that Makhawan watershed is a fifth-order basin. High drainage density in the Makhawan watershed is observed over denudational hills having impermeable subsurface material, sparse vegetation with hilly terrain, whereas low drainage density is found over permeable subsurface material and low relief. However, low relief areas along alluvial plains and some depression in Deccan Plateau which are illustrated by low drainage density are suitable sites for identification of prospective groundwater areas. It has been observed from the analysis that streams of watershed are in late youth stage of geomorphic development and has been attributed to the phenomenon of rejuvenation, which has direct relationship with runoff and erosional status of the area. Form factor and circularity ratio show that all the subwatersheds have elongated shape, whereas elongation ratio depicts that out of seven subwatersheds, four subwatersheds suggest higher susceptibility to erosion whereas rest of the three subwatersheds have high infiltration capacity and low runoff. In the present study, morphometric analysis has been carried out using GIS techniques to assess the hydrological characteristics of Makhawan watershed and an attempt has been made to identify the qualitative assessment of groundwater prospective areas in semi-arid climatic conditions for judicious planning and management of conservation measures at micro-level to conserve available natural resources, which will be helpful to various stakeholders such as water resources management and policy-makers for better decision-making, particularly, in the data-scarce areas. The present study also reveals that the hydrological evaluation derived from SRTM data are more applied and accurate compared to other techniques at subwatershed level.

Acknowledgements Authors are thankful to the Chairman, Department of Geology, Aligarh Muslim University, Aligarh, for encouragement and providing necessary infrastructure facilities of the remote sensing lab. Help rendered by H.H. Khan during preparation of thematic maps is acknowledged. Thanks are also due to M.H. Wani for fruitful discussion and assistance during the field check. The first author gratefully thanks University Grants Commission for providing financial assistance in the form of Junior Research Fellowship. The constructive comments and suggestions of the editor and anonymous reviewers have improved the quality of the paper.

Open Access This article is distributed under the terms of the Creative Commons Attribution 4.0 International License (http:// creativecommons.org/licenses/by/4.0/), which permits unrestricted use, distribution, and reproduction in any medium, provided you give appropriate credit to the original author(s) and the source, provide a link to the Creative Commons license, and indicate if changes were made.

\section{References}

Agarwal CS (1998) Study of drainage pattern through aerial data in Naugarh area of Varanasi district, U.P. J Indian Soc Remote Sens 24(4):169-175

Baumgardner RW (1987) Morphometric studies of subhumid and semiarid drainage basin, Texas Panhandle and Northeastern New Mexico. Report of Investigations, issue 163. Bureau of Economic Geology, University of Texas at Austin

Brice J (1984) Meandering pattern of the White River in Indiana-an analysis. In: Morisawa MO (ed) Fluvial geomorphology. State University of New York Press, Binghamton, pp 178-200

Burrough PA (1986) Principles of geographical information systems for land resource assessment. Oxford University Press, New York, p 50

Chopra R, Dhiman RD, Sharma PK (2005) Morphometric analysis of sub-watersheds, district Gurdaspur, Punjab. J Indian Soc Remote Sens 33(4):531-539

Chorley RJ, Dale PF (1972) Cartographic problems in stream channel delineation. Cartography 7:150-162

Chow VT (1964) Handbook of applied hydrology. In: Chow VT (ed) A compendium of water-resources technology. McGraw-Hill, New York, pp 43-56 
Deshpande GG (1998) Geology of Madhya Pradesh. Geological Survey of India, Banaglore, pp 1-223

Drummond RR (1974) When is a stream a stream? Prof Geogr 26:34-37

Dwivedi RS, Sreenivas K, Ramana KV, Reddy PR, Sankar GR (2006) Sustainable development of land and water resources using geographic information system and remote sensing. J Indian Soc Remote Sens 34(4):351-367

Ebisemiju FF (1994) The sinuosity of alluvial river channels in the seasonally wet tropical environment: case study of River Elmi, South Western Nigeria. Catena 24:13-25

Farr TG, Kobrick M (2000) Shuttle radar topography mission produces a wealth of data. EOS Trans Am Geophys Union 81:583-585

Frissel CA, Liss WJ, Warren CE, Hurley MD (1986) A hierarchical framework for stream habitat classification: viewing streams in a watershed context. Environ Manag 10(2):109-114

Gorokhovich Y, Voustianiouk A (2006) Accuracy assessment of the processed SRTM-based elevation data by CGIAR using field data from USA and Thailand and its relation to the terrain characteristics. Remote Sens Environ 104:289-315

Gregory KJ (1976) Drainage networks and climate. In: Derbyshire E (ed) Geomorphology and climate. Wiley, Chichester, pp 409-415

Gregory KJ, Gardiner V (1975) Drainage density and climate. Z Geomorphol 19:287-298

Grohmann CH, Riccomini C, Alves FM (2007) SRTM-based morphotectonic analysis of the Pocos de caldas alkaline massif Southeastern Brazil. Comput Geosci 33:10-19

Hadely RF, Schumm SA (1961) Sediment sources and drainage basin characteristics in upper Cheyenne River basin. United State Geological Survey water-supply paper, 1531-B, pp 137-196

Horton RE (1932) Drainage basin characteristics. Trans Am Geophys Union 13:350-361

Horton RE (1945) Erosional development of steams and their drainage density: hydrophysical approach to quantitative geomorphology. Geol Soc Am Bull 56:275-370

Javed A (1995) Remote sensing applications for land system studies in Bulandshahr district, U.P., India. Ph.D. thesis, Aligarh Muslim University, Aligarh (unpublished)

Javed A, Khanday MY, Ahmad R (2009) Prioritization of subwatersheds based on morphometric and land use analysis in Guna district (M.P.): a remote sensing and GIS based approach. J Indian Soc Remote Sens 2(37):261-274

Khanday MY (2009) Characterization and prioritization of watersheds in parts of Guna district, Madhya Pradesh, using remote sensing and GIS techniques. Ph.D. thesis, Aligarh Muslim University, Aligarh (unpublished)

Khanday MY, Javed A (2008) Impact of climate change on land use/land cover in Chopan Watershed, Guna District (M.P.), using remote sensing and GIS. J Environ Res Dev 2(4):568-579

Khanday MY, Javed A (2016) Prioritization of sub-watersheds for conservation measures in a semi arid watershed using remote sensing and GSI. J Geol Soc India 88:185-196

Krishnamurthy J, Srinivas G, Jayaram V, Chandrasekhar MG (1996) Influence of rock type and structure in the development of drainage networks in typical hard rock terrain. ITC J 3/4:252-259

Krumbein WC, Shreve RL (1970) Some statistical properties of dendritic channel networks. Technical report no. 13, US. Office of Naval Research Contract Nonr-1228(36), Task no. 389-150, Department of Geological Sciences, Northwestern University, and Special Project Report, National Science Foundation Grant GA-1137, Department of Geology, University of California, Los Angeles
Kumar R, Kumar S, Lohni AK, Neema RK, Singh AD (2000) Evaluation of geomorphological characteristics of a catchment using GIS. GIS India 9(3):13-17

Langbein WB (1947) Topographic characteristics of drainage basins. U.S. Geological Survey Water-Supply Paper 986(C), pp 157-159

Leopold LB, Miller JP (1956) Ephemeral streams: hydraulic factors and their relation to the drainage net. U.S. Geological Survey Professional Paper 282-A

Leopold LB, Wolman MG, Miller JP (1964) Fluvial processes in geomorphology. Freeman, San Fransisco, CA

Lotspeich FB, Platts WS (1982) An integrated land-aquatic classification system. N Am J Fish Manag 2:138-149

Lubowe JR (1964) Stream junction angles in the dendritic drainage pattern. Am J Sci 262:325-339

Macka Z (2001) Determination of texture of topography from large scale contour maps. Geogr Vestn 73(2):53-62

Maidment DR (2002) ArcHydro GIS for water resources. Esri Press, Redlands

Mark DM (1983) Relation between field-surveyed channel network and map-based geomorphometric measures, Inez Kentucky. Ann Assoc Am Geogr 73(3):358-372

Melton MA (1957) An analysis of the relations among elements of climate, surface properties and geomorphology. Project NR 389-042, Technical report 11, Columbia University, Department of Geology, ONR, Geography Branch, New York

Mesa LM (2006) Morphometric analysis of a subtropical Andean basin (Tucumam, Argentina). Environ Geol 50(8):1235-1242

Miller VC (1953) A quantitative geomorphic study of drainage basin characteristics on the Clinch Mountain area, Virginia and Tennessee. Project NR 389-402, Technical report 3, Columbia University, Department of Geology, ONR, New York

Montgomery DR, Dietrich WE (1989) Source areas, drainage density and channel initiation. Water Resour Res 25:1907-1918

Morisawa ME (1959) Relation of quantitative geomorphology to stream flow in representative watersheds of the Appalachian Plateau Province. Project NR 389-042, Technical report 20, Columbia University, Department of Geology, ONR, Geography Branch, New York

Nag SK, Chakraborty S (2003) Influence of rock types and structures in the development of drainage network in hard rock area. J Indian Soc Remote Sens 31(1):25-35

Nautiyal MD (1994) Morphometric analysis of drainage basin, district Dehradun,Uttar Pradesh. J Indian Soc Remote Sens 22(4):252-262

Nooka Ratnam K, Srivastava YK, Venkateshwara Rao V, Amminedu E, Murthy KSR (2005) Check dam positioning by prioritization of micro-watersheds using SYI model and morphometric analysis-remote sensing and GIS perspective. J Indian Soc Remote Sens 33(1):25-38

O'callaghan J, Mark DM (1984) The extraction of drainage networks from digital elevation data. Comput Vis Graph Image Process 28:323-344

Pradhan B (2009) Ground water potential zonation in Basaltic watersheds using satellite remote sensing data and GIS techniques. Cent Eur J Geosci 1(1):120-129

Reddy OPG, Maji AK, Chary GR, Srinivas CV, Tiwary P, Gajbhiye KS (2002) Geo spatial database for prioritization and evaluation of conservation strategies for landscape management in a river basin. In: Navalgund RR et al (eds) Proceedings of ISPRS Commission VII, symposium on resources and environmental monitoring, vol 1, pp 654-659, Hyderabad, India

Rinaldo A, Rodriguez-Iturbe I, Rigon R (1998) Channel networks. In: Jeanloz R, Albee AL, Burke KC (eds) Annual review of earth and planetary sciences, vol 26. Annu Rev, Palo Alto, pp 289-327

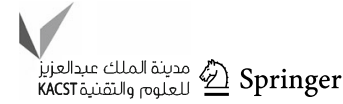


Sarkar BC, Deota BS, Raju PLN, Jugran DK (2001) A geographic information system approach to evaluation of groundwater potentiality of Shamri micro-watershed in the Shimla Taluk, Himachal Pradesh. J Indian Soc Remote Sens 29(3):151-164

Schumm SA (1956) Evolution of drainage systems and slopes in badland, at Perth Amboy, New Jersey. Geol Soc Am Bull 67:597-646

Schumm SA, Khan HR (1972) Experimental study of channel patterns. Geol Soc Am Bull 83:1755-1770

Shreve RL (1966) Statistical law of stream numbers. J Geol 74:17-37

Singh S, Singh MC (1997) Morphometric analysis of Kanhar river basin. Natl Geogr India 43(1):31-34

Singh P, Verma SK, Khan S (2002) Hydrological framework and Development Prospects of Guna District, Madhya Pradesh. CGWB, Bhopal, Madhya Pradesh (unpublished)

Singh P, Thakur J, Singh UC (2013) Morphometric analysis of Morar River Basin, Madhya Pradesh, India, using remote sensing and GIS techniques. Environ Earth Sci 68:1967-1977

Singh P, Gupta A, Singh M (2014) Hydrological inferences from watershed analysis for water resource management using remote sensing and GIS techniques. Egypt J Remote Sens Space Sci 17:111-121

Smith KG (1950) Standards for grading textures of erosional topography. Am J Sci 248:655-668

Solanke PC, Srivastava R, Prasad J, Nagaraju MSS, Saxena RK, Barthwal RK (2005) Application of remote sensing and GIS in watershed characterization and management. J Indian Soc Remote Sens 33(2):239-244

Sreedevi PD, Subrahmanyam K, Ahmad S (2005) The significance of morphometric analysis for obtaining ground water potential zones in a structurally controlled terrain. Environ Geol 47(3):412-420

Sreedevi PD, Owais S, Khan HH, Ahmad S (2009) Morphometric analysis of a watershed of South India, Using SRTM and GIS data. J Geol Soc India 73:543-552

Srinivasa VS, Govindainah S, Gowda HH (2004) Morphometric analysis of Sub-watersheds in the Pavagada area of Tumkur district South India using remote sensing and GIS techniques. J Indian Soc Remote Sens 32(4):351-362

Strahler AN (1952) Quantitative geomorphology of erosional landscape. In: 19th International Geological Congress, Algiers, sec. 3, vol 3, pp 342-354

Strahler AN (1957) Quantitative analysis of watershed geomorphology. Trans Am Geophys Union 38:913-920

Strahler AN (1964) Quantitative geomorphology of drainage basins and channel networks. In: Chow VT (ed) Handbook of applied hydrology. McGraw-Hill, New York, pp 4.39-4.76

Tarboton DG, Bras RL, Rodriguez-Iturbe I (1991) On the extraction of channel networks from digital elevation data. TT Hydrol Process 5:81-100

Trucker GE, Bras RL (1998) Hillslope processes, drainage density and landscape morphology. Water Resour Res 34:2751-2764

Verstappen HTH (1983) Applied geomorphology. ITC, Enschede 